\title{
Genetic diversity of sugar palm (Arenga pinnata) derived from nine regions in Indonesia based on SSR markers
}

\author{
DIAN YUNITA RINAWATI ${ }^{1}$, REFLINUR $^{2}$, DINY DINARTI ${ }^{1}$, SUDARSONO $^{1, \bullet}$ \\ ${ }^{1}$ Plant Molecular Biology Laboratory, Department Agronomy and Horticulture, Faculty of Agriculture, Institut Pertanian Bogor. Jl. Meranti, IPB \\ Dramaga Campus, Bogor 16680, West Java, Indonesia. Tel.: +62-251-8622642, `email: sudarsono_agh@apps.ipb.ac.id \\ ${ }^{2}$ Indonesian Center for Agricultural Biotechnology and Genetic Resource Research and Development. Jl. Tentara Pelajar No. 3A, Bogor 16111, West \\ Java, Indonesia.
}

Manuscript received: 29 July 2021. Revision accepted: 18 August 2021.

\begin{abstract}
Rinawati DY, Reflinur, Dinarti D, Sudarsono. 2021. Genetic diversity of sugar palm (Arenga pinnata) derived from nine regions in Indonesia based on SSR markers. Biodiversitas 22: 3749-3755. Sugar palm (Arenga pinnata (Wurmb) Merr.) has an important economic and conservation value. Indonesia has genetic diversity potential of sugar palm, considering the widespread distribution of sugar palm in Indonesia which has variations in geographical type. This study aims to determine the diversity and relationship of sugar palm from nine regions in Indonesia based on SSR markers. The genetic material consists of 141 sugar palm accessions derived from Bangka, Lampung, Lebak, Bogor, Tasikmalaya, Brebes, Gowa, Bombana, and Muna. Nine pairs of SSR primers were used for genotyping. The highest and lowest genetic diversity was found in the Bangka and Muna populations, respectively. The genetic diversity within a population (79\%) was higher than the genetic diversity between populations $(21 \%)$. The genetic distance between Bangka and Lebak is the closest (0.033), while between Lampung and Muna is the farthest (0.283). The accession relationship is divided into three major clusters. Clusters 1 consisted of Bangka, Lampung, Bogor, Tasikmalaya, Brebes, Gowa, Bombana and Muna accessions. Cluster 2 consisted of Bangka, Lampung, Lebak, Bogor, Tasikmalaya, Brebes, and Gowa accessions. Cluster 3 consisted of Bangka, Lebak, Brebes, Tasikmalaya, and Gowa accessions. Accession clustering does not show a typical relationship pattern based on geographic location.
\end{abstract}

Keywords: Arenga pinnata, genetic diversity, genetic distance, SSR, sugar palm

\section{INTRODUCTION}

Sugar palm (Arenga pinnata (Wurmb) Merr.) is an annual plant of the palm family (Arecaceae) that is adaptive to various types of agro-climate and land conditions. It extensively spreads in Indonesia, inhabits from lowland to highland. Sugar palm has a dense root system which makes it suitable for the conservation of soil and water (Effendi 2015). All parts of the plant can be utilized. Since a long time ago, the community has used sugar palm trees for various domestic purposes, according to local wisdom. Sugar palm leaves and stems are used for household appliances and building materials. The pith or medulla stem of an old palm tree contains starch that can be processed into flour. Endosperm seeds from unripe fruit can be processed into kolang-kaling, which has a high dietary fiber content. Palm tree roots can be used to treat kidney stones and toothache. Sugar palm flowers can be tapped to produce sap that can be processed into sugar, and as raw material bioethanol (Lim 2012). Lately, the utilization of sugar palm oil leads to industrial purposes, such as in the bioethanol industry, natural fiber industry, and food industry.

The potential of sugar palm commodity development is broadly quite attractive in line with the industry's need for sugar palm plant products. The development of sugar palm in marginal land can be considered to obtain economic benefits, conservation, and avoid land-use competition with other crop commodities. Small-scale sugar palm cultivation has been done by farmers using intercropping planting systems, but the production value is not much different from wild palm crops. Better production potential can be obtained if technological innovations are available, including superior varieties and superior palm seeds. The breeding of sugar palm plants is needed to produce superior varieties through hybridization or superior seeds of the selected parent tree.

Germplasm is very important as the source of genetic material in plant breeding programs. The assortment genetic diversity in the collection of germplasm can be utilized to assemble new varieties that have certain superior traits, such as high sap production potential and lateflowering. Indonesia's diverse geographical and agroclimate types are very prospective in identifying the genetic diversity. Genetic diversity of the plants among regions can be formed because of human activities and natural factors that last for a long period (Zhou et al. 2020). The management and utilization of germplasm will be more effective and efficient if genetic diversity information is available (Elshibli and Korpelainen 2011).

Identifying the genetic diversity of germplasm at this time is widely done by utilizing molecular markers as a selection tool. One of the DNA markers that are often used in evaluating the genetic diversity of a plant commodity is the SSR (Simple Sequence Repeats) marker based on PCR (Polymerase Chain Reaction). SSR markers on the plant 
genome are quite abundant, so their use can produce a high level of polymorphism. The SSR mark is codominant, which means it can identify heterozygous loci. The reproducibility of SSR markings is also relatively high (Nadeem et al. 2018). Genetic diversity studies of several species of palm plants have been successfully conducted using SSR markers, including in oil palm (Arias et al. 2015; Bakoume et al. 2015; Ithnin et al. 2017), Nypa fruticans (Jian et al. 2010), date palm (Elmeer et al. 2011; Al-Faifi et al. 2016; Ahmed et al. 2021), and coconut (Mahayu and Taryono 2019).

This study aims to study the genetic diversity and genetic relationship of palms from nine regions in Indonesia based on the analysis of SSR markings. The results of this study are expected to provide information about the genetic diversity of sugar palm from Indonesia so that the management and utilization of palm germplasm for crop breeding programs can be more precise and efficient.

\section{MATERIALS AND METHODS}

\section{Plant materials}

The genetic material used in this study consists of 144 accession sugar palm from nine regions in Indonesia, namely Bangka (10 accessions), Lampung (16 accessions), Lebak (16 accessions), Bogor (11 accessions), Tasikmalaya (10 accessions), Brebes (26 accessions), Gowa (13 accessions), Bombana (13 accessions), and Muna (29 accessions).

\section{DNA isolation}

The DNA genome of a total of 144 accessions of palm was isolated from palm leaves using the modified CTAB
2\% (gL-1) (Doyle and Doyle 1990) method with modification of polyvinylpyrrolidone additions of $0.2 \%$ $\left(\mathrm{mL} \mathrm{L}^{-1}\right)$ and mercaptoethanol $2 \%\left(\mathrm{gL}^{-1}\right)$ of the extraction buffer volume. The concentration and purity of DNA stock were tested using the Thermo Scientific ${ }^{\mathrm{TM}} 2000$ microvolume spectrophotometer tool. Test results with a value of A260/280 1.8 show that DNA stock already has good purity. Furthermore, DNA stock is stored in a $1 \mathrm{x}$ TE (Tris-EDTA) $\mathrm{pH} 8.0$ buffer solution at $-20^{\circ} \mathrm{C}$ until the DNA stock is ready for use.

Before use for PCR analysis needs, DNA stocks are diluted using sterile $\mathrm{ddH}_{2} \mathrm{O}$ until the concentration of DNA solution is in the range of $20 \mathrm{ng} \mu \mathrm{L}^{-1}$. The concentration and quality of DNA dilution results are confirmed through electrophoresis techniques with $1 \mathrm{x}$ TBE buffer solution by including standard $\lambda \mathrm{DNA}$ with concentrations of $10 \mathrm{ng} \mu \mathrm{L}^{-1}$, $20 \mathrm{ng} \mu \mathrm{L}^{-1}$, and $50 \mathrm{ng} \mu \mathrm{L}^{-1}$ as comparisons.

\section{Genotyping uses SSR markers}

A total of nine pairs (forward + reverse) of SSR primers gone through polymorphism selection are used for genotyping 144 palm accessions originating from nine regions. PCR is performed using a Bio-Rad Thermal Cyclers T100TM machine with a total reaction solution volume of $20 \mu \mathrm{L}$. The composition of the reaction solution consists of $10 \mu \mathrm{L}$ MyTaq HS Red Mix $2 x, 1.6 \mu \mathrm{L}$ primer

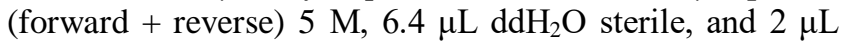
DNA template $\left(20 \mathrm{ng} \mu \mathrm{L}^{-1}\right)$. PCR begins with a predenaturation stage at $94^{\circ} \mathrm{C}$ for 5 minutes, followed by denaturation at $94^{\circ} \mathrm{C}$ for 30 seconds, annealing at $55^{\circ} \mathrm{C}$ for 1 minute, elongation at $72^{\circ} \mathrm{C}$ for 1 minute, extension at $72^{\circ} \mathrm{C}$ for 15 minutes, and temperature $4^{\circ} \mathrm{C}$ for 5 minutes. The denaturation stage up to elongation lasts 35 cycles.

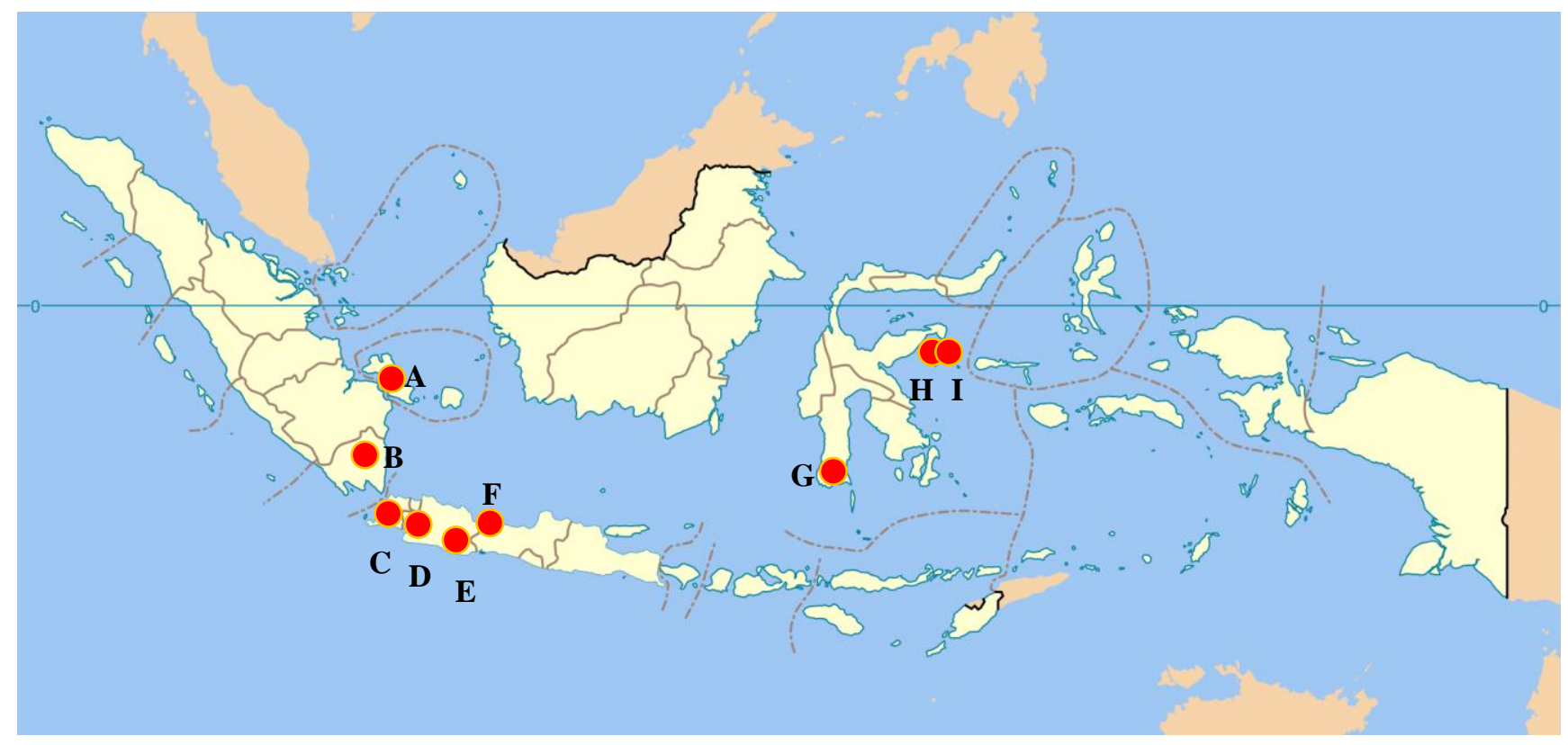

Figure 1. The map of study sites of sugar palm population in Indonesia. A. Bangka, B. Lampung, C. Lebak, D. Bogor, E. Tasikmalaya F. Brebes, G. Gowa, H. Bombana, I. Muna 
PCR product separation is done through electrophoresis technique on polyacrylamide gel $5 \%$ printed in a sandwich plate with $1 \mathrm{x}$ TBE solution as a buffer. Pre-run is performed at $55^{\circ} \mathrm{C}$ and $120 \mathrm{~W}$ power for 60 minutes for the gel to be denatured. A total of $5 \mu \mathrm{L}$ PCR products from each accession number were transferred to the new PCR plate, then denatured at $95^{\circ} \mathrm{C}$ for 5 minutes. The PCR plate is moved to a container containing ice shards, and $1 \mu \mathrm{L} 3 \mathrm{x}$ STR loading dye is added to the PCR product. After the pre-run is complete, as many as $5 \mu \mathrm{L}$ of PCR products from each accession are inserted into each well on the gel using micropipettes. A total of $3 \mu \mathrm{L}$ DNA ladder $100 \mathrm{bp}$ is inserted into the front well so that later PCR product size can be estimated. The GT top safety cover is reconnected with an electric current source. Electrophoresis is run at $50^{\circ} \mathrm{C}$ and $100 \mathrm{~W}$ of electrical power until the lightest dye loading color reaches the bottom of the gel.

The sandwich plate is disassembled by separating short glass and long glass. The gel attached to the short glass then goes through the stages of fixing, staining, developing, and stopping. Fixing stage: immersion in $2 \mathrm{~L}$ of glacial acetic acid solution $10 \%$ for 20 minutes, then rinsed using $2 \mathrm{~L} \mathrm{ddH_{2 }}$ O for 5 minutes twice. Staining: immersion in $2 \mathrm{~L}$ of silver nitrate solution for 30 minutes, then rinsed with 2 $\mathrm{L} \mathrm{ddH}_{2} \mathrm{O}$ for 10 seconds. Developing: immersion in the developer solution for 5 minutes or until DNA tape appears. Stopping: soaking for 10 minutes in a solution previously used for fixing, then rinsed with $2 \mathrm{~L} \mathrm{ddH}_{2} \mathrm{O}$ for 10 minutes. The glass is then placed in a vertical position for one night so that the gel attached to the glass is dehydrated. All immersion and flushing stages are performed on a separate box on top of the shaker engine at a speed of $5 \mathrm{rpm}$. The PCR amplification tape shown on the glass is rated 1,2, 3, and so on according to the number of alleles identified to obtain allelic data for analysis.

\section{Data analysis}

The genotyping data were analyzed using GeneAlEx 6.5 software to determine the number of alleles $(\mathrm{Na})$, the number of effective alleles (Ne), observation heterozygosity (Ho), and the heterozygosity of expectations (He), the percentage of genetic diversity in the population and between populations, as well as the genetic distance between populations. PIC (Polymorphism Information Content) indicates informativity of primer obtained from data analysis using Cervus 3.0.7 software. Phylogenetic analysis was conducted with Darwin 6.0.14 software to obtain the relationship of accessions.

\section{RESULTS AND DISCUSSION}

\section{Polymorphism, allele frequency, and heterozygosity}

The informativity of primer is represented by the primer's ability to detect polymorphism between individuals. The PIC value is the causation of primer informativity. The PIC value range for the codominant mark is 0 to 1 . According to Botstein et al. (1980), primer informativity levels are categorized as high (PIC >0.5), moderate $(0.25 \leq \mathrm{PIC} \leq 0.5)$, and low $(\mathrm{PIC}<0.25)$. There were two primers with high informativity in this study, namely AD647 and AD707, with PIC values of 0.547 and 0.551 , respectively. The other four primers have moderate informativity, namely AD87, AD299, AD 499, and AD139, with PIC values of $0.304,0.413,0.373$, and 0.322 , respectively. Primers AD623, AD655, and AD671 are low informativity levels with PIC values of $0.207,0.020$, and 0.007 .

Terryana et al. (2019) analyzed the genetic diversity of sugar palm using a highly informative SSR primer with PIC values between 0.937 and 0.951 . It is alleged that because the accession tested came from three populations with different types of growth, so the chances of allele variations were higher. The accession samples in this study were taken randomly without information on the differences in traits for a particular character between accessions and between populations. The low PIC value of a primary is caused by the low genetic variation of accession tested on the primary locus. The chances of obtaining an informative primer to analyze genetic diversity can be increased by multiplying the number of primers selected before genotyping.

Testing 144 palm accessions from nine populations based on the regional origin on nine SSR loci resulted in 24 alleles. The number of alleles per locus varies from two to four alleles, with an average of 2,667 alleles per locus. The level of genetic diversity in the SSR locus is indicated by $\mathrm{Ne}, \mathrm{He}$, and PIC values. The higher the value of these three variables, the higher the genetic diversity of accession (Zhou et al. 2020). The average scores of Ne, He, and PIC were $1,558,0.292$, and 0.305 , respectively, indicating that the genetic diversity in the study was not so high. Among the nine loci tested (Table 1), the AD671 locus produced the lowest genetic diversity with $\mathrm{Ne}, \mathrm{He}$, and PIC values of 1,009, 0,008, and 0.007, respectively. The highest genetic diversity of sugar palm was obtained from the LOCUS AD647 with $\mathrm{Ne}, \mathrm{He}$, and PIC values of 2,075, 0.465, and 0.547 , respectively. Thus, primary AD647 is quite well used to study the genetic diversity sugar palm population based on the origin of different regions.

\section{Genetic diversity of populations}

Genetic diversity can be attributed to gene variations within a population or between populations passed down between generations. Natural selection, spontaneous mutations, gene flow, genetic drift, and inbreeding can affect the population's genetic diversity (Jaradat 2015). The highest genetic diversity is owned by the population of Bangka with a value of $\mathrm{Ne} 1.811$ and $\mathrm{He} 0.355$. Muna's population has the lowest level of genetic diversity, with $\mathrm{Na} 1.447$ and $\mathrm{He} 0.255$.

A comparison of Ho and He values may indicate the level of heterozygosity (Zhou et al. 2020). Among the nine sugar palm populations in this study, the populations of Lebak, Tasikmalaya, and Brebes had low heterozygosity based on Ho values that were smaller than the values (Table 2). Long-term crossing with individuals from outside the population and the process of adaptation to the 
environment can affect heterozygosity levels (Aljuhani 2016). In the populations of Lebak, Tasikmalaya, and Brebes, it is suspected that the incidence rate of crossings with individuals from outside the population is shallow, and environmental changes have not very successfully stimulated the response of significant adaptations of individuals in the population, thus not giving rise to new alleles.

Analysis of molecular variance results shows that accession genetic diversity in the population is $79 \%$, while genetic diversity between populations amounts to $21 \%$ of the total genetic diversity available (Table 3). FSt and P values of 0.205 and 0.001 respectively indicate marked genetic differences, and accession genetic differences in populations contribute greatly to total genetic diversity. In this study, the genetic diversity of sugar palm in the population was higher than the genetic diversity between populations. Other studies on genetic diversity in sugar palm (Harjanto et al. 2011; Terryana et al. 2020), sago (Abbas et al. 2010), oil palm (Okoye et al. 2016), and date palm (Al-Faifi et al. 2016) show similar results.

Low genetic diversity among the general population is found in the annual cross-pollinating plant (Zhou et al. 2020). Cross-pollinating annual forest plant species generally have genetic diversity in populations higher than genetic diversity between populations (Porth and El-
Kassaby 2014). Cross-pollination can produce recombinants that have genetic variations. One bunch of female palm flowers consists of hundreds of flowers and has the opportunity to be randomly pollinated by pollen from other sugar palm trees in the vicinity. One female flower bunch can produce hundreds of seeds with different genetic compositions. In natural populations, the mature palm fruit can fall from trees or be dispersed with the help of wild animals. The seeds can grow into new palm trees with different genotypes that form high genetic diversity in the population. The long-distance distribution of plant genetic material between regions involves the role of human mobility, especially those related to agricultural activities and trade in agricultural commodities (Bakoumé et al. 2015).

The status of sugar palm as a plant that has not been widely domesticated causes gene flow from outside of the population through human migration to be very limited, so that the genetic diversity between sugar palm populations is lower than the genetic diversity within the population The percentage of genetic diversity in the population and between populations can be considered in selecting sugar palm accessions for conservation purposes or plant breeding materials. For efficiency, the number of palm sugar sampling areas is not very large, but the number of samples taken from each location can be increased.

Table 1. Polymorphism, allele frequency, and heterozygosity in nine loci of SSR

\begin{tabular}{lcccccccccc}
\hline & & & & \multicolumn{9}{c}{ Locus } & & & \\
& AD87 & AD623 & AD647 & AD655 & AD671 & AD707 & AD299 & AD499 & AD139 & Average \\
\hline $\mathrm{Na}$ & 2.000 & 2.000 & 4.000 & 2.000 & 2.000 & 4.000 & 3.000 & 2.000 & 3.000 & 2.667 \\
$\mathrm{Ne}$ & 1.529 & 1.315 & 2.075 & 1.033 & 1.009 & 1.903 & 1.931 & 1.753 & 1.470 & 1.558 \\
$\mathrm{Ho}$ & 0.438 & 0.272 & 0.439 & 0.031 & 0.009 & 0.333 & 0.630 & 0.533 & 0.387 & 0.341 \\
$\mathrm{He}$ & 0.317 & 0.224 & 0.465 & 0.028 & 0.008 & 0.438 & 0.460 & 0.417 & 0.267 & 0.292 \\
$\mathrm{Fst}$ & 0.098 & 0.049 & 0.277 & 0.069 & 0.034 & 0.316 & 0.085 & 0.165 & 0.190 & 0.143 \\
$\mathrm{Nm}$ & 2.307 & 4.803 & 0.651 & 3.396 & 7.031 & 0.540 & 2.700 & 1.268 & 1.068 & 2.641 \\
$\mathrm{PIC}$ & 0.304 & 0.207 & 0.547 & 0.020 & 0.007 & 0.551 & 0.413 & 0.373 & 0.322 & 0.305 \\
\hline
\end{tabular}

Na: number of alleles, Ne: number of effective alleles, Ho: observed heterozygosity, He: expected heterozygosity, Fst: number of inbreeding effect within population, Nm: gene flow, PIC: polymorphism information content

Table 2. Genetic diversity of sugar palm populations from nine regions

\begin{tabular}{cccccccccc} 
& \multicolumn{9}{c}{ Population } \\
\cline { 2 - 10 } & Bangka & Lampung & Lebak & Bogor & Tasikmalaya & Brebes & Gowa & Bombana & Muna \\
\hline $\mathrm{Na}$ & 2.333 & 2.333 & 2.000 & 2.000 & 1.889 & 2.000 & 2.444 & 2.000 & 2.000 \\
$\mathrm{Ne}$ & 1.811 & 1.618 & 1.544 & 1.542 & 1.568 & 1.474 & 1.542 & 1.471 & 1.447 \\
$\mathrm{Ho}$ & 0.456 & 0.410 & 0.257 & 0.333 & 0.298 & 0.248 & 0.394 & 0.291 & 0.387 \\
$\mathrm{He}$ & 0.355 & 0.327 & 0.286 & 0.274 & 0.300 & 0.265 & 0.301 & 0.261 & 0.255 \\
\hline
\end{tabular}

Na: number of alleles, Ne: effective allele number, Ho: observed heterozygosity, He: expected heterozygosity

Table 3. Genetic diversity within and between populations of sugar palm derived from nine regions

\begin{tabular}{lccccc}
\hline Sources of diversity & $\begin{array}{c}\text { degrees of } \\
\text { freedom }\end{array}$ & $\begin{array}{c}\text { Sum of } \\
\text { squares }\end{array}$ & $\begin{array}{c}\text { Middle squared } \\
\text { value }\end{array}$ & $\begin{array}{c}\text { Estimated } \\
\text { variance }\end{array}$ & Percentage variance \\
\hline Between populations & 8 & 96.277 & 12.035 & 0.342 & $21 \%$ \\
Within population & 279 & 368.890 & 1.322 & 1.322 & $79 \%$ \\
Total & 287 & 465.167 & & 1.644 & $100 \%$ \\
\hline Fst $=0.205$ & $\mathrm{P}=0.001$ & & & \\
\hline
\end{tabular}

Note: Fst: number of inbreeding effects within a population, P: Probability component of variance that does not explain the total variance 


\section{Genetic distance and relationship}

Genetic differences between populations of a species can be represented by genetic distance value (Okoye et al. 2016). The genetic distance is shown based on values 0 to 1 . The value of the genetic distance closer to 1 indicates an increasingly large genetic difference. In this study, the value of genetic distance ranged from 0.033 to 0.283 . Bangka and Lebak populations have the closest genetic distance (0.033), while the furthest genetic distance between Lampung and Muna populations (0.283). Terryana et al. research (2020) reveal that populations in closer geographic areas tend to have closer genetic distances to each other. Lebak's population is geographically located on the Java islands, such as Bogor, Tasikmalaya, and Brebes, but the genetic distance is closer to the different Bangka island populations, and the geographical distance is getting farther. The mountain that became a barrier among Lebak, Bogor, Tasikmalaya, and Brebes is thought to have a strong isolation effect on the four populations (Table 4).

The population of sugar palm from the western region of Indonesia (Bangka, Lampung, Lebak, Bogor, Tasikmalaya, and Brebes) tends to have a close genetic distance from each other, as well as between populations from the central region of Indonesia (Bombana and Muna). Species spread influenced by geological, historical events, such as the separation of continents, the formation of mountains, and changes in sea level height (Wiens and Donoghue 2004). Past land-level segregation events have affected the spread and diversity of species in Southeast Asia (Eiserhardt et al. 2011).

The western region of Indonesia, which includes the islands of Sumatra, Java, and Kalimantan in the past era is a Sundaland that merges with the Asian continent. In contrast, the central region of Indonesia, including Sulawesi, is separated as its land (Bird et al. 2005). Based on geological history, the western and central regions of Indonesia are two different biogeographic regions. It does not close the possibility that the close genetic distance between populations in one biogeographic region is due to those populations from the same ancestors. Different trends are seen in Gowa populations that come from the central region but have a genetic distance closer to the populations of the western regions. Similarly, (Sulistyawati and Widyatmoko 2017) reported that the genetic distance of
Timor Island's redwood population is closer to the redwood population of Seram Island compared to the population of Flores Island, which is geographically closer.

The results of the phylogenetic analysis showed that the sugar palm of the nine populations was divided into three major clusters (Figure 1). Each cluster consists of accessions originating from various populations. Cluster 1 consists of accessions from Bangka, Lampung, Bogor, Tasikmalaya, Brebes, Gowa, Bombana and Muna. Cluster 2 consists of accessions from Bangka, Lampung, Lebak, Bogor, Tasikmalaya, Brebes, and Gowa. Cluster 3 consists of accessions from Bangka, Lebak, Brebes, Tasikmalaya, and Gowa. The sugar palm accessions in this study had genetic relationship patterns that spread into all three clusters, except for accession from Muna populations whose relationship patterns only grouped in cluster 1 . Certain accessions of different island populations or even different biogeographic regions have a close genetic relationship. For example, in cluster 1, the accession of the populations of Bogor, Tasikmalaya, and Brebes in Java Island is closely related to the accession of Bangka population and Lampung population of different islands, even still related to the accession of Gowa, Bombana, and Muna which are in the biogeographical region of central Indonesia. This indicates the role of ocean currents in the history of the widespread palm oil in the Indonesian archipelago. Ocean currents play a major role in helping the long-range spread of Araceae family palm plants between islands, including in the Indo-Pacific archipelago (Baker and Couvreur 2012). In the species Aquilegia coerulea, the occurrence of long-distance dispersal of pollen through the assistance of hawkmoth migration is thought to cause genetic similarities between populations from different regions of the United States separated by great geographical distances and large desert barriers (Brunet et al. 2012). The results of the research by Harjanto et al (2011) showed a random pattern in the grouping of sugar palms based on isozyme markers. The grouping of sugar palms from Java, Sumatra, Kalimantan, and Sulawesi islands does not show a pattern of relationship groups based on geographical location. In general, the pattern of accession grouping does not indicate a typical tendency of palm genetic relationship based on geographical location.

Table 4. Genetic distance between the populations of sugar palm

\begin{tabular}{|c|c|c|c|c|c|c|c|c|c|}
\hline & $\mathbf{A}$ & B & $\mathbf{C}$ & D & $\mathbf{E}$ & $\mathbf{F}$ & $\mathbf{G}$ & $\mathbf{H}$ & I \\
\hline $\bar{A}$ & - & & & & & & & & \\
\hline B & 0.048 & - & & & & & & & \\
\hline $\mathrm{C}$ & 0.030 & 0.059 & - & & & & & & \\
\hline $\mathrm{D}$ & 0.074 & 0.082 & 0.070 & - & & & & & \\
\hline $\mathrm{E}$ & 0.073 & 0.047 & 0.075 & 0.039 & - & & & & \\
\hline $\mathrm{F}$ & 0.111 & 0.145 & 0.064 & 0.144 & 0.098 & - & & & \\
\hline $\mathrm{G}$ & 0.082 & 0.056 & 0.095 & 0.051 & 0.042 & 0.163 & - & & \\
\hline $\mathrm{H}$ & 0.157 & 0.197 & 0.143 & 0.134 & 0.104 & 0.075 & 0.160 & - & \\
\hline $\mathrm{I}$ & 0.220 & 0.283 & 0.186 & 0.262 & 0.228 & 0.072 & 0.275 & 0.049 & - \\
\hline
\end{tabular}

Note: A: Bangka, B: Lampung, C: Lebak, D: Bogor, E: Tasikmalaya, F: Brebes, G: Gowa, H: Bombana,I: Muna. 


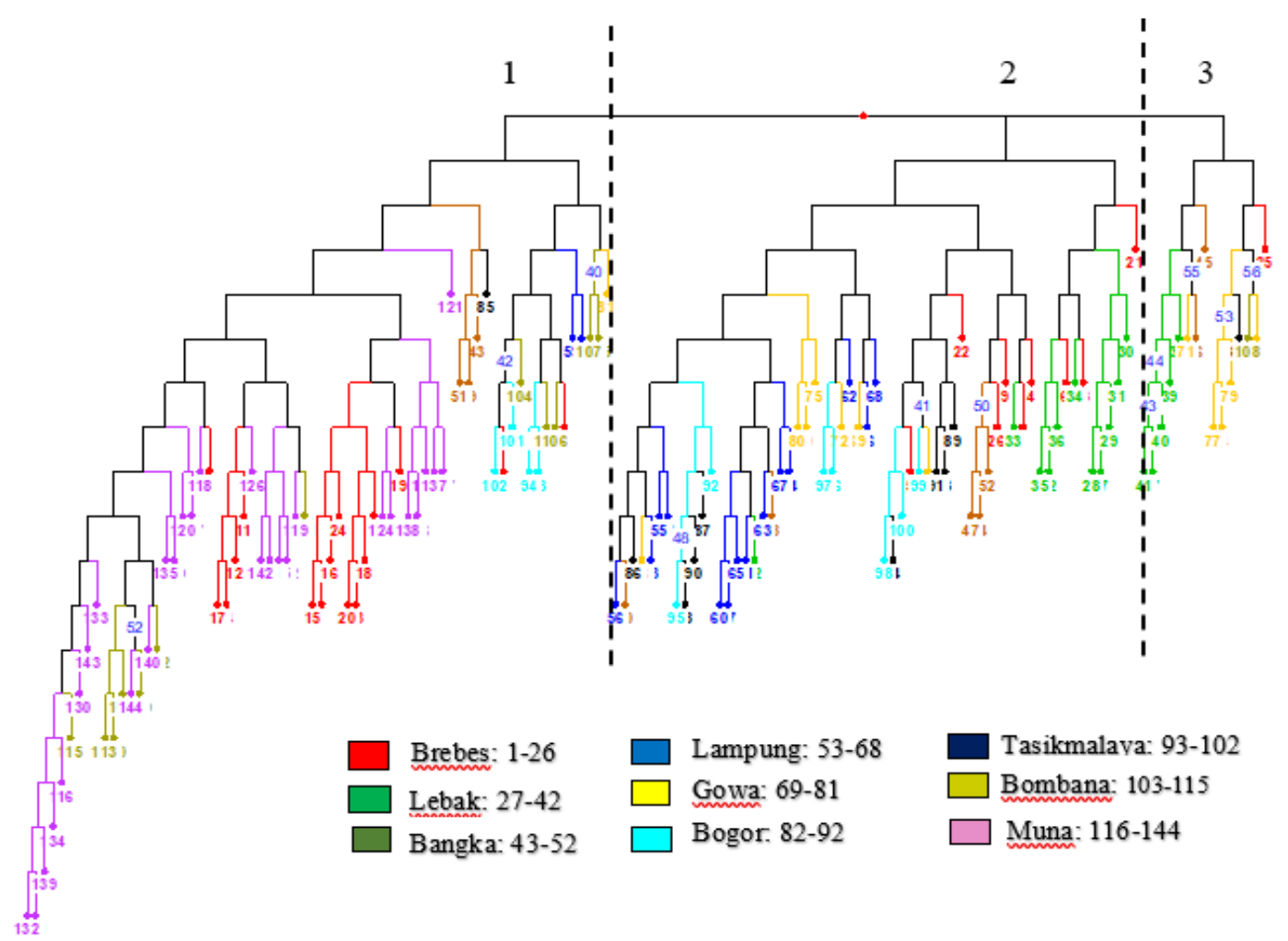

Figure 2. Sugar palm phylogenetic trees from nine regions based on the method Tree Construction-Neighbour Joining

All accessions of the Muna population in one relationship cluster show that there are no significant genetic structural differences between accessions in the Muna population. This is thought to be because Muna populations are on small islands quite isolated, so gene flow from outside the population is minimal. There is the accession of the Bombana population in one relationship cluster with accession to the Muna population. Bombana and Muna are geographically separated by narrow straits, making it possible that gene flow between them is possible.

\section{ACKNOWLEDGEMENTS}

The author would thank Indonesian Center for Agricultural Biotechnology and Genetic Resource Research and Development for the material support and facilities provided for this study.

\section{REFERENCES}

Abbas B, Renwarin Y, Bintoro MH. 2010. Genetic diversity of sago palm in Indonesia based on chloroplast DNA (cpDNA) markers. Biodiversitas 11: 112-117. DOI: 10.13057/biodiv/d110302.

Ahmed W, Feyissa T, Tesfaye K, Farrakh S. 2021. Genetic diversity and population structure of date palms (Phoenix dactylifera L.) in Ethiopia using microsatellite markers. J Genet Eng Biotechnol 19: 114. DOI: $10.1186 / \mathrm{s} 43141-021-00168-5$

Al-Faifi SA, Migdadi HM, Algamdi SS, Khan MA, Ammar MH, AlObeed RS, Al-Thamra MI, El-Harty EH, Jakse J. 2016. Development, characterization and use of genomic SSR markers for assessment of genetic diversity in some Saudi date palm (Phoenix dactylifera L.) cultivars. Elect J Biotechnol 21:18-25. DOI: 10.1016/j.ejbt.2016.01.006

Aljuhani WS. 2016. Genetic diversity and the impact of geographical location on the relationships between Phoenix dactylifera L. germplasms grown in Saudi Arabia. Hered Genet 5 (3): 1000172. DOI: $10.4172 / 2161-1041.1000172$.

Arias D, González M, Prada F, Ayala-Diaz I, Montoya C, Daza E, Romero HM. 2015. Genetic and phenotypic diversity of natural American oil palm (Elaeis oleifera (H.B.K.) Cortés) accessions. Tree Genet. Genomes 11 (6): 122. DOI: 10.1007/s11295-015-0946-y.

Baker WJ, Couvreur TLP. 2012. Biogeography and distribution patterns of Southeast Asian palms. In: Gower D, Johnson K, Richardson J, Rosen B, Rüber L, Williams S (eds.). Biotic Evolution and Environmental Change in Southeast Asia. Cambridge University Press, Cambridge.

Bakoume C, Wickneswari R, Siju S, Rajanaidu N, Kushairi A, Billotte N. 2015. Genetic diversity of the world's largest oil palm (Elaeis guineensis Jacq.) field genebank accessions using microsatellite markers. Genet Resour Crop Ev 62 (3): 349-360. DOI: 10.1007/s10722-014-0156-8.

Bird MI, Taylor D, Hunt C. 2005. Palaeoenvironments of insular Southeast Asia during the Last Glacial Period: A savanna corridor in Sundaland?. Quart Sci Rev 24: 2228-2242. DOI: 0.1016/j.quascirev.2005.04.004

Botstein D, White RL, Skalnick MH, Davies RW. 1980. Construction of a genetic linkage map in man using restriction fragment length polymorphism. Am J Hum Genet 32 (3): 314-331.

Brunet J, Larson-Rabin Z, Stewart CM. 2012. The distribution of genetic diversity within and among populations of the rocky mountain columbine: the impact of gene flow, pollinators, and mating system. Intl J Plant Sci 173 (5): 484-494. DOI: 10.1086/665263.

Doyle JJ, Doyle JL. 1990. Isolation of plant DNA from fresh tissue. Focus 12: 13-15. DOI: 10.1007/978-3-642-83962-7_18

Effendi DS. 2015. Prospek pengembangan tanaman aren (Arenga pinnata Merr) mendukung kebutuhan bioetanol di Indonesia. Perspektif 9: 3646. [Indonesian]

Eiserhardt WL, Svenning JC, Kissling WD, Balslev H. 2011. Geographical ecology of the palms (Arecaceae): Determinants of 
diversity and distributions across spatial scales. Ann Bot 108: (8) 1391-1416. DOI: 10.1093/aob/mcr146.

Elmeer K, Sarwath H, Malek J, Baum M, Hamwieh A. 2011. New microsatellite markers for assessment of genetic diversity in date palm (Phoenix dactylifera L.). 3 Biotech 1 (2): 91-97.

Elshibli S, Korpelainen H. 2011. Biodiversity in date palm: molecular markers as indicators. In: Jain SM, Al-Khayri JM, Johnson DV (eds.) Date Palm Biotechnology. Springer, Dordrecht.

Haryjanto L, Prastyono P, Ismail B. 2011. Keragaman genetik empat populasi Arenga pinnata Merr berdasarkan penanda isozim. J Pemuliaan Hutan Tanaman 5: 13-21. [Indonesian]

Ithnin M, Teh CK, Ratnam W. 2017. Genetic diversity of Elaeis oleifera (HBK) Cortes populations using cross species SSRs: Implication's for germplasm utilization and conservation. BMC Genet 18 (37): 1-12. DOI: $10.1186 / \mathrm{s} 12863-017-0505-7$

Jaradat AA. 2015. Biodiversity, genetic diversity, and genetic resources of date palm. In: Al-Khayri J, Jain S, Johnson D (eds) Date Palm Genetic Resources and Utilization. Springer, Dordrecht.

Jian S, Ban J, Ren H, Yan H. 2010. Low genetic variation detected within the widespread mangrove species Nypa fruticans (Palmae) from Southeast Asia. Aquat Bot 92 (1): 23-27. DOI: 10.1016/j.aquabot.2009.09.003.

Lim TK. 2012. Arenga pinnata. Edible Medicinal and Non-Medicinal Plants Volume 1: Fruits. Springer, Dordrecht.

Mahayu WM, Taryono. 2019. Coconut (Cocos nucifera L.) diversity in Indonesia based on SSR molecular marker.In: Nuringtyas TR, Hidayati L, Rafieiy M (eds). Proceeding of $1^{\text {st }}$ International Conference on Bioinformatics, Biotechnology, and Bioinformatics Engineering, Universitas Gadjah Mada, Yogyakarta, 19-20 October 2018. [Indonesia].
Nadeem MA, Nawaz MA, Shahid MQ, Doğan Y, Comertpay G, Y1ldız M, Hatipoğlu R, Ahmad F, Alsaleh A, Labhane N, Özkan H, Chung G, Baloch FS. 2018. DNA molecular markers in plant breeding: current status and recent advancements in genomic selection and genome editing. Biotechnol Biotech Eq 32 (2): 261-285. DOI: 10.1080/13102818.2017.1400401

Okoye MN, Bakoumé C, Uguru MI, Singh R, Okwuagwu CO. 2016. Genetic relationships between elite oil palms from Nigeria and selected breeding and germplasm materials from Malaysia via Simple Sequence Repeat (SSR) Markers. J Agric Sci 8:159-178. DOI: $10.5539 /$ jas.v8n2p159.

Porth I, El-Kassaby YA. 2014. Assessment of the genetic diversity in forest tree populations using molecular markers. Diversity 6 (2): 283295. DOI: $10.3390 / \mathrm{d} 6020283$

Sulistyawati P, Widyatmoko A. 2017. Genetic diversity in kayu merah (Pterocarpus indicus Willd) populations using random amplified polymorphism DNA marker. J Pemuliaan Tanaman Hutan 11: 67-76.

Terryana RT, Nugroho K, Lestari P. 2020. Genetic Diversity of Sugar Palm Populations from Cianjur and Banten revealed by Simple Sequence Repeat (SSR) Markers. Better Environment with Better Prosperity, Harmonization of Humankind and Nature; Proceeding of 1st International Conference on Sustainable Plantation. IPB University, Bogor, 20-22 August 2019. [Indonesian]

Wiens JJ, Donoghue MJ. 2004. Historical biogeography, ecology and species richness. Trends Ecol Evol. 19 (12): 639-644. DOI: 10.1016/j.tree.2004.09.011

Zhou Q, Mu K, Ni Z, Liu X, Li Y, Xu L an. 2020. Analysis of genetic diversity of ancient Ginkgo populations using SSR markers. Ind Crops Prod 145: 111942. DOI: 10.1016/j.indcrop.2019.111942 